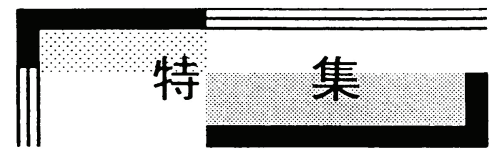

\title{
白川河口干潟の土砂動態と地形変化*
}

\section{Sediment Transport and Morphological Changes at the Mouth Delta of Shirakawa River}

\author{
辻 本 剛 三** \\ TSUJIMOTO Gozo
}

\begin{abstract}
Intertidal mudflats are important for land conservation, flooding risk alleviation and biological environment. Mudflat profiles have been measuring monthly along some cross-shore lines exceeding $1,000 \mathrm{~m}$ in the vicinity of a river mouth since December 2000. For the mud profile evolution, the annual accretion rate was $4.2 \mathrm{~cm} /$ year and $1.6 \mathrm{~cm} /$ year on the right and left lines, the seasonal variation in the range $-5 \mathrm{~cm}$ and $5 \mathrm{~cm}$, and the maximum episodic variation $12.1 \mathrm{~cm}$ and $22.0 \mathrm{~cm}$. The wind waves could play many contributions for deposition and erosion of sediment. Sediment budgets based on the monthly bed level and net sediment flux monitoring were estimated to examine the relative contributions of tides and river discharge to sediment transport. The estimated sediment budgets are interpreted using the water mass balance equation and the horizontal tidal current pattern. The intertidal flat accreted during normal discharge conditions are primarily attributable to the alongshore sediment flux toward the river mouth. However, the flat was eroded when the large offshore suspended sediment transport occurred on the flat during the large river discharge. The net alongshore tidal current causes alongshore sediment fluxes toward the river mouth on this intertidal flat adjacent to the river mouth. In observation periods, there were two times of a significant flood occurred on July 12, 2012 with the discharge water rates of $2,300 \mathrm{~m}^{3} / \mathrm{s}$ and on June 21,2016 with $1,600 \mathrm{~m}^{3} / \mathrm{s}$. Also two earthquakes scaled of 7 on the Japanese scale struck Kumamoto Prefecture on April 14 and 16, 2016, and then about the $0.4 \mathrm{~m}$ ground subside was occurred at the present field site. A large amount of sediment from Shirakawa River was discharged into the delta due to the flood. The clinoform along the water route approximately propagated $150 \mathrm{~m}$ in the offshore direction and the bed level increased by $1.5 \mathrm{~m}$. The estimated sediment discharge was $1.1 \times 105 \mathrm{~m}^{3} / \mathrm{yr} / \mathrm{km}^{2}$ during 2014 to 2016 , corresponds four times during 1978 to 1997.
\end{abstract}

Keywords: Delta propagation, Equilibrium profiles, Tide, Wave, River discharge

\section{1. 緒 言}

全国の沿岸域の自然環境は 20 世紀後半の経済 発展とともに大きく変貌し、遠浅な水域では埋め 立てや港湾構造物等の整備に伴い干潟域の消失 は著しく、環境省の調査によれば、例えば有明海 の干潟面積は 1978 年から 1997 年の間に、22,070 ha から 20,391 ha に減少している。近年は地球温 暖化による海面上昇や台風の巨大化に伴う外力 の変化により、干潟の脆弱性が増している。

干潟は背後地に対する減災機能や豊かな生態 系などその存在意義は決めて高く、近年、それら の重要性を定量的に評価する手法が検討されて
いる[1]。干潟は干潮時に海底面が露出する砂泥地 であり、地形の特色により河口干潟、潟湖干潟、 前浜干潟、入江干潟に分類される。干潟は「前置 層」と呼ばれる河川から流出した砂泥が海岸部に 堆積した上に形成されており、波・流れ等の外力 の変化により底泥は容易に移動するため、前置層 の存在下で成り立っているために、継続的な土砂 供給が重要である。将来に亘って干潟を保全・維 持するためには、干潟における底泥の動態と地形 変動の把握は極めて重要であるが、国内の干潟が 形成される海域は限られているため、工学的な立 場からの研究はそれほど多くない。

* 2019.1.26 受付

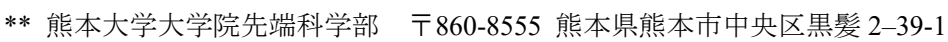

TEL: (096)342-3545 E-mail: tgozo@kumamoto-u.ac.jp 


\section{2. 白川河口干潟}

有明海は $1700 \mathrm{~km}^{2}$ の海域面積を有し、大潮時 の潮位差は場所にもよるが、最大 $4 \sim 5 \mathrm{~m}$ に及ん でいる。有明海には嘉瀬川、筑後川、矢部川、菊 池川、白川、緑川が流入し、河川の流域面積は $8,000 \mathrm{~km}^{2}$ に及んでいる。大きな干満差と河川か らの土砂供給により湾内では、我が国の干潟の約 $40 \%$ が形成されている。熊本県も広大な干潟を有 しており、県全体の約 6 割にあたる、6,566 ha の 干潟が有明海に現存している。

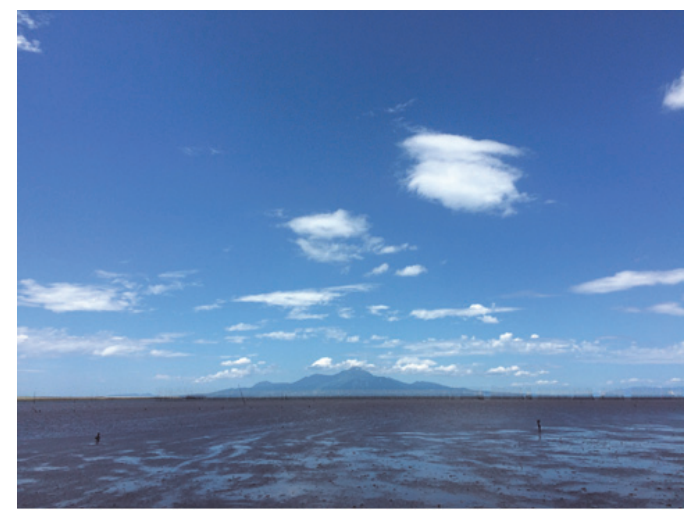

Photo 1 View of Shirakawa River Delta.

筆者が所属する大学の南側には流域面積 480 $\mathrm{km}^{2}$ 、幹川流路延長 $74 \mathrm{~km}$ を有する白川が流れ、 その河口域にはPhoto 1 に示すような広大な白川 河口干潟が広がっている。白川流域の $80 \%$ は降水 量が全国平均 2 倍程度の阿蘇カルデラがあり、そ こに源を有する白川と黒川が外輪山の切れ目で 合流して、阿蘇山からの排出される火山灰等は白 川河道を通じて有明海に流出している（Fig. 1)。

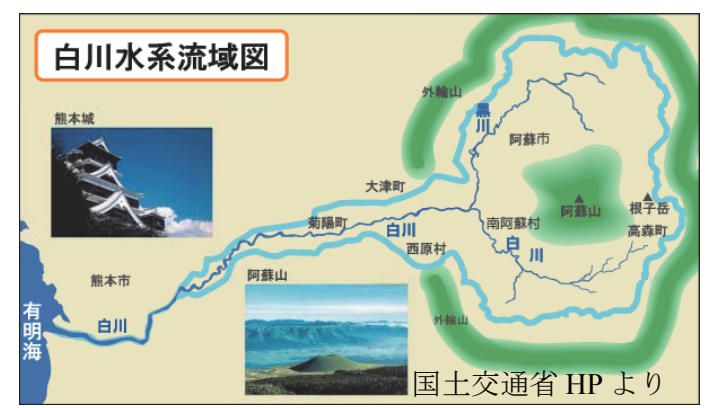

Fig. 1 Map of Shirakawa River Basin.

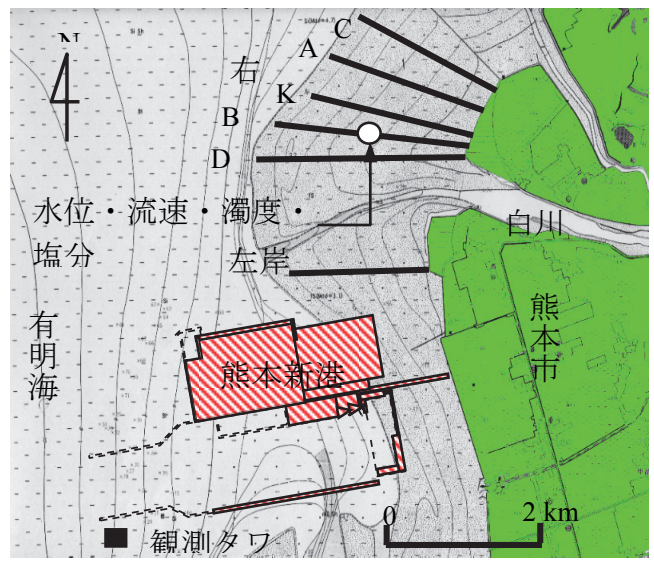

Fig. 2 Field site over the intertidal mudflat at Shirakawa River mouth.

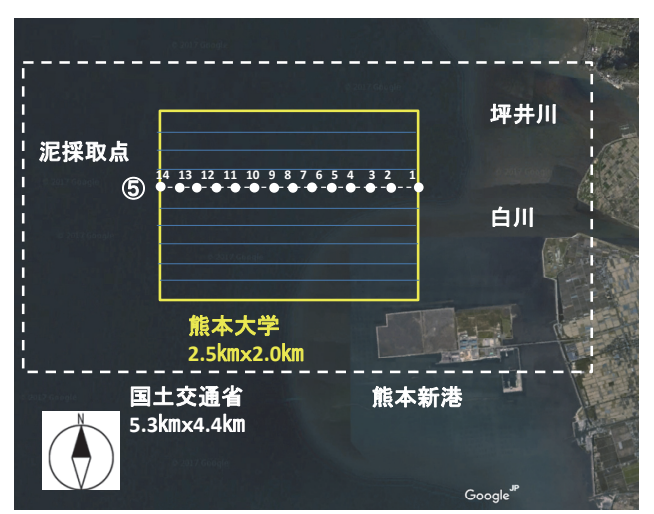

Fig. 3 Measuring area of echo sounding adjacent to Shirakawa River mouth.

熊本大学は白川河口干潟で 2000 年 12 月から地 盤高の現地観測が実施され、筆者は 2016 年 4 月 に観測等を引き継いでいる。本稿はこれまでの取 り組みと現況について報告する[2-13]。

\section{3. 現地調査の概要}

\section{1 地盤高観測}

観測は Fig. 2 に示寸熊本県白川河口域に広が る潮間帯干潟上で実施した。トータルステーショ ン（SOKIA SET3A）を用いて 50 m 間隔で岸沖 方向最大 $1.5 \mathrm{~km}$ を計測した。図中には複数の測 線があるが、本稿では左岸と右岸 $\mathrm{K}$ について主 として述べる。また、Fig. 3 に示寸 $2.5 \mathrm{~km} \mathrm{x} 2$ km の潮下帯において 2013、2014、2016、2017、2018 
年と 5 回、船上から ADCP を用いて深浅測量を実 施した。図中の破線枠 $(5.3 \mathrm{~km}$ x $4.4 \mathrm{~km})$ は国土 交通省による 1976 年から 2003 年までの調查範囲 であり、本研究の観測範囲はこの範囲に含まれて いる。

\section{2 物理諸量の観測}

詳細な底質の動態を把握するために、2004 年 7 月 30 日から 8 月 5 日の大潮から中潮にかけて右 岸の側線 B において水位、流速、濁度、塩分の連 続観測を行った。観測方法として、水位は底面に 設置した水圧式波高計で計測した圧力から換算 し、流速は底面上 $10 \mathrm{~cm}$ に設置した波高・波向・ 流速計を用いて計測した（WaveHunter99、アイオ 一テクニック)。水位・流速はそれぞれ $5 \mathrm{~Hz}$ 間隔 で計測している。濁度は赤外後方散乱式濁度計 (COMPACT-CLW、アレック電子) を底面上 10 $\mathrm{cm}$ と $30 \mathrm{~cm}$ の水深方向 2 点に設置し、塩分は小 型メモリー水温塩分計（COMPACT-CT、アレッ ク電子）を底面上 $30 \mathrm{~cm}$ の位置で固定し、それぞ れ 10 分毎に $1 \mathrm{~Hz}$ 間隔で 20 秒間計測した。観測 した水位・流速データは最小自乗法を用いて平均 流と波浪成分とに分離し、濁度は現地泥を用いた 検定試験より SS 濃度に換算した。

\section{4. 観測結果}

\section{1 干潟の岸沖断面変化の機構[2]}

毎月の地盤高測量の結果から、毎年 6 月 10 月に生じる約 $40 \mathrm{~cm}$ の季節的な平均潮位の上 昇・干潟地形はタイムラグもなく約 $5 \mathrm{~cm}$ の堆 積・侵食を繰り返していることが分かったが、そ の要因については十分に明らかにされていなか った。

Fig. 4 は 2001 年 2 月から熊本地震前の左岸に

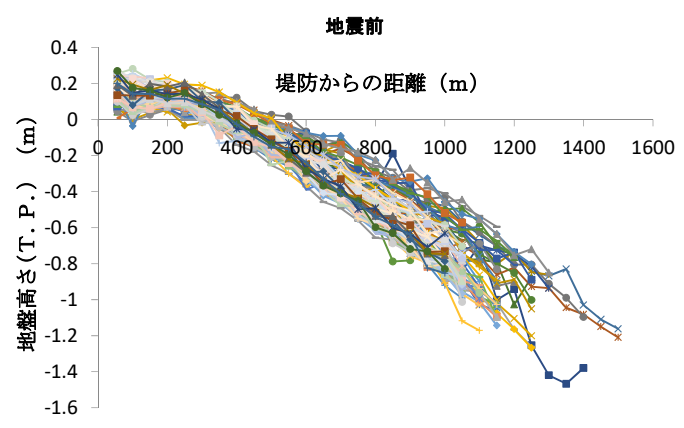

Fig. 4 Measured cross-shore profiles.
おける岸沖断面形状の全観測結果である。上に凸 状の地形となり、平均勾配は 1/900 程度である。 また、沖側の地形変動が岸側よりも著しく、通常 の砂浜海岸とは異なる。1 潮汐間における上げ 潮・下げ潮時の最大流速差の時系列と相間が高く、 平均潮位の季節昇降に伴い平均流速場の非対称 性の増大が、干潟の堆積・侵食機構の主要因であ ることが示唆された。

\section{2 潮間帯上の底質輸送フラックス[3]}

干潟上の底質輸送過程には、潮汐・波浪・河川 等の複数の外力が複雑に作用しており、その詳細 は未解決である。そのために、潮汐と波浪の寄与 率や潮位差の影響についての議論が必要である。 しかしながら、干潟では干出と水没が繰り返され る、不等間隔・不連続な観測值となってしまうた め、スペクトル解析による、時系列の周波数成分 分離が困難であった。新たに潮汐位相平均による 分析方法を提案して両者の分離を行い、潮汐が卓 越した場合と台風時の突発的な外力変動時の底 質輸送の特徵について検討を行った。

Fig. 5 は浮遊フラックスの時空間変動のベクト ルを示す。上げ潮・下げ潮時は地形の等高線に直 交する底質輸送が生じ、満潮時にも白川側への有 意な底質輸送が存在し、1 潮汐間では白川向きの 輸送が卓越することがわかった。平均的な潮汐に 伴う潮間帯上の濁度变化は、流れによる移流効果 が支配的であり、台風時には高波浪による底質の 局所的な巻き上げが卓越する。底質の移動フラッ クの方向は、上げ潮・下げ潮ともに潮汐の影響

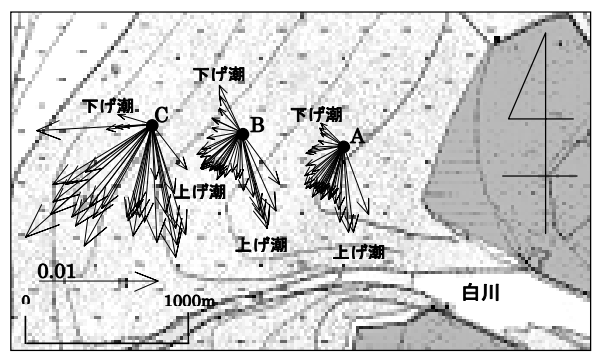

Fig. 5 Variation of suspended sediment flux.

が支配的であるが、満潮時には白川の流出の影響 を受けており、1 潮汐間では白川向きの輸送が卓 越している。

\section{3 潮間帯上の底質輸送特性とモデル[4]}

底質輸送には浮遊形式と掃流形式があるが、両 者の干潟地形変動に及ぼす影響は明確にされて 
いない。そこで、浮遊フラックスと底面流速の 3 次モーメントを用いて浮遊・掃流輸送能力を算定 し、相対波高との関係について検討した。また、 底質輸送に及ぼす波浪と潮汐の影響を岸沖方向 3 点で評価し、岸沖分布特性を検討することで、底 質の岸沖方向輸送の概念モデルを考察した。

Fig. 6 は潮汐が卓越する場合の底質輸送の概念 モデルを示す。潮間帯上の底質輸送特性には相対 波高值が 0.2 付近に波・流れ卓越性の閾值が存在 し、相対波高の増大に伴い底質輸送への波浪の影

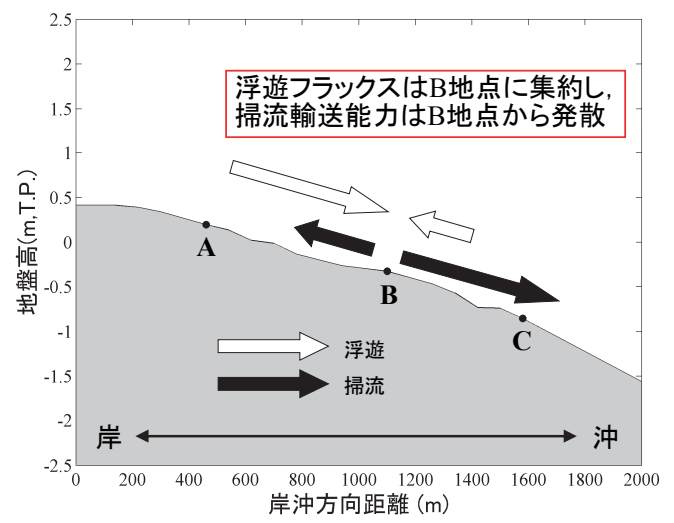

Fig. 6 Sediment transport over mud flat.

響が 1 桁程度増大寸ることが明らかとなった。提 案した底質輸送モデルにより、岸沖方向の凸状の 干潟地形は、平常時の掃流移動による中間潮間帯 へ収束することで維持されている可能性が示唆 された。

\section{4 土砂収支法の提案と潮間帯への適用 [5]}

出水時に白川から流出した土砂は、河道・澪 筋・潮下帯に一旦堆積寸るため、河川からの土砂 量によって地形は大きく変動している。しかしな がら、従来の土砂収支では、供給量の 2 倍程度に 相当する量の土砂堆積が算出されることや沖側 一年間 35 万 $\mathrm{m}^{3}$ の土砂流出が推定されるなど、定 量的な精度に関しては検証が必要である。そこで、 地盤高データと底質輸送フラックの計測を併用 し、シルト・粘土の質量に基づいた土砂収支法を 構築する。潮間帯において土砂収支を算定し、河 川出水量と土砂動態との関係について検討した。

Fig. 7 に土砂収支を検討するための解析領域を 示す。平常時には北側の潮間帯には北から南の

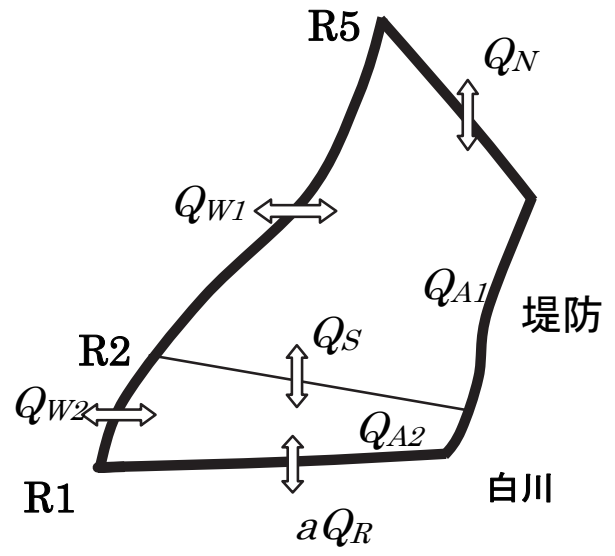

Fig. 7 Analytical area of sediment transport budget.

河口付近に向から輸送フラックスにより、堆積傾 向を示している。また、南側の潮閒帯では、河川 からの流入するシルト・粘土の約 $14 \%$ が堆積し、 地形変化をもたらしている。一方、出水時には多 量のシルト・粘土が沖側に流出するために、潮間 帯全域において侵食傾向となる。

\section{5 土砂動態への潮汐と河川の相対的重要度 [6]}

干潟の短期地形変動には高波浪、平均的変動に は潮汐、長期的変動には河川出水が重要とされて いる。しかしながら、土砂収支に基づく潮汐・河 川出水の相対的な重要度の検討はされていない。 そこで、地盤高と底質浮遊フラックを連続的に調 ベる事で、出水時の土砂動態に及ぼす河川出水の ピークと潮汐の位相差の影響について検討した。

Fig. 8 に出水時の河川流量と潮位の時系列を示 す。出水は下げ潮時から生じ、干潮時には出水の ピークとなっており、潮間帯の底質は下げ潮時の 沖向き流れが過剩な河川水によって南側に輸送

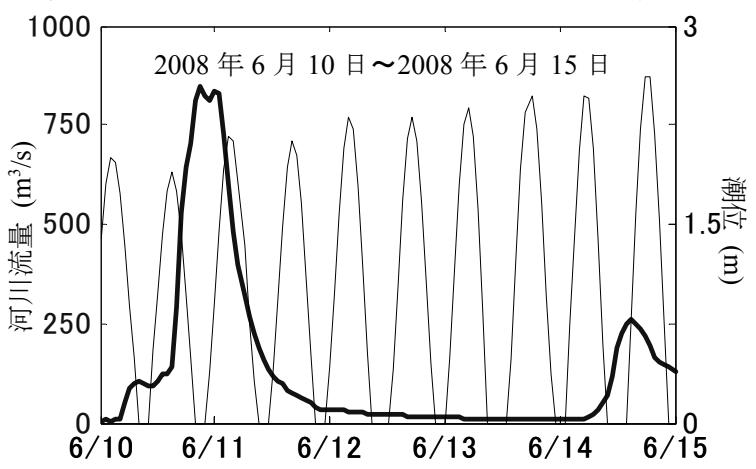

Fig. 8 Time series of river discharge and tidal level. 
される。平時の底質浮遊フラックが時間変化に岸 沖・沿岸方向に変化しており、土砂収支は一致し ている。河川の出水のピークと潮汐の干潮時ある いは満潮時と位相差によって土砂の移動方向が 異なることが確認された。

\section{6 異常出水による干潟地形の影響[7]}

平成 24 年 7 月 12 日未明から大雨により、白川 の源流付近である阿蘇乙姫では、7月 11 日 0 時か ら 14 日 24 時までに観測された最大 1 時間降雨量 が $108 \mathrm{~mm}$ 、最大 24 時間降水量が $507.5 \mathrm{~mm}$ とな り、それぞれ観測史上 1 位の值となった。このよ うな極端気象現象による干潟の地形変動とその 適応回復の検討は、沿岸防災の観点から極めて重 要である。

Fig. 9 に出水後の 9 月に熊本県と共同で行った 河口域の深浅測量と泥堆積厚の結果を示す。

底泥の堆積厚は、岸沖方向に対して沖側に向か って増大し、河口から $1,500 \mathrm{~m}$ 付近で約 $0.5 \mathrm{~m}$ で あった。また、沿岸方向では河口付近の潮間帯の 領域ではさらに堆積量が多い傾向であった。平成 18 年 1 月〜平成 24 年 12 月までの鉛直変位パラ メータの変動を比較することで、平均堆積量は約 $30 \mathrm{~cm}$ を超え、過去の最大值の 3 倍以上になって いる。

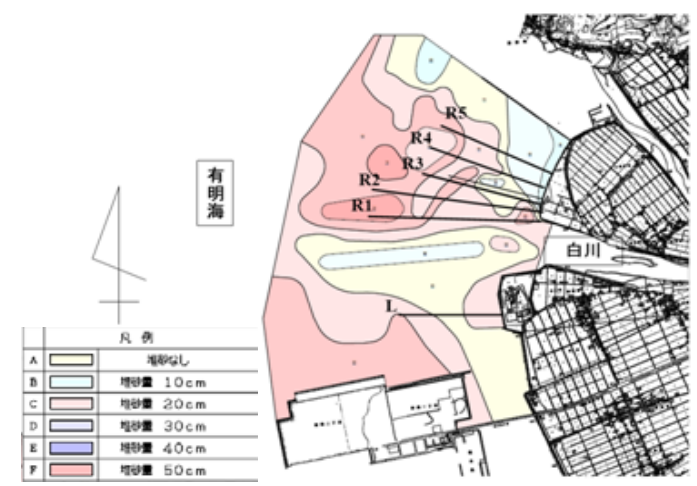

Fig. 9 Spatial distributions of mud thickness.

\section{7 長期地形変動予測モデル $[8,9]$}

将来の気象変動に伴う海面上昇や外力変化に より沿岸域の地形は大きく影響を受けることが 予測される。河口干潟は極めて平坦で脆弱であり、 その影響が顕著である。そのために詳細な地形変 化過程の予測は数多く実施されている。しかしな がら、長期の予測においてこれらのモデルを利用
することは計算負荷の観点から適切ではない。 Swenson ら[14]の移流拡散モデルに、干潟を陸上 デルタと海中デルタに区分し、突発的な豪雨によ る河川出水と強風等による波浪の影響率によっ て前置層の前進過程を表現できるように改良し た。Fig. 10 に観測と計算の結果の例を示す。潮 間帯から潮下帯に遷移する地点は roll over point と呼ばれ事前に設定しているため、潮間帯まで再 現は比較的良好であるが、前置層の発達の再現は 良くない。

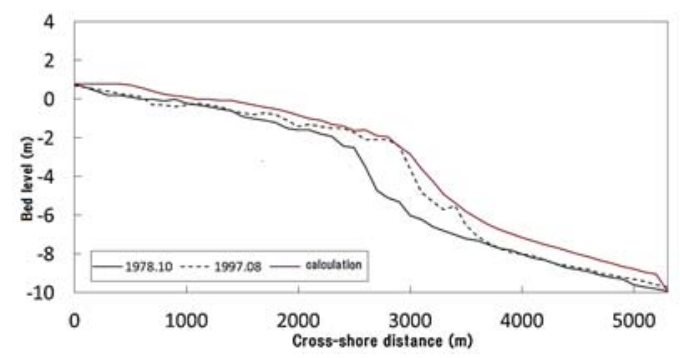

Fig.10 Comparison of prediction model and measurements of cross-shore profile.

さらに長期の河ロデルタ地形を予測するため に、潮汐・波浪および河川出水による土砂供給の 3 つの外力変化を考慮した岸沖 1 次元の河ロデル 夕地形長期予測モデルの構築を行い、白川河口域 に適用して、外力変化に対する地形の応答を予測 した。モデルは Mariotti ら[15]が提案しているモ デルを参照し、流体運動、底質輸送、地形変化の 3 つのプロセスを 1 サイクルとし、計算を繰り返 している。さらに、将来の海面上昇の影響を考慮 した検討も行った。Fig. 11 に観測值と計算結果 の比較を示す。潮間帯での一様な堆積が見られ、 観測值と同様な傾向であるが、潮下帯での一様な 堆積傾向や前置層の先端位置は、観測值と異なる。

また、このモデルによる将来の検討では、海面 上昇により白川河口デルタにおいて平均 35〜45 $\mathrm{cm}$ 程度の地盤の低下が生じる。

\section{8 熊本地震後の地形変動 $[10,13]$}

2016 年 4 月に発生した 2 回の震度 7 の熊本地震 では地盤沈下が生じ、白川河口域においても約 $50 \mathrm{~cm}$ 程度の地盤沈下が生じた。また、阿蘇山麓 において大規模な斜面崩壊が生じ、およそ 5.9 $\mathrm{km}^{2}$ に及ぶ崩壊・不安定斜面が形成され、6月 18 日から 23 日にかけて白川の源流付近である阿蘇 乙姫では総雨量 $502 \mathrm{~mm}$ の雨量を記録し、総雨量 


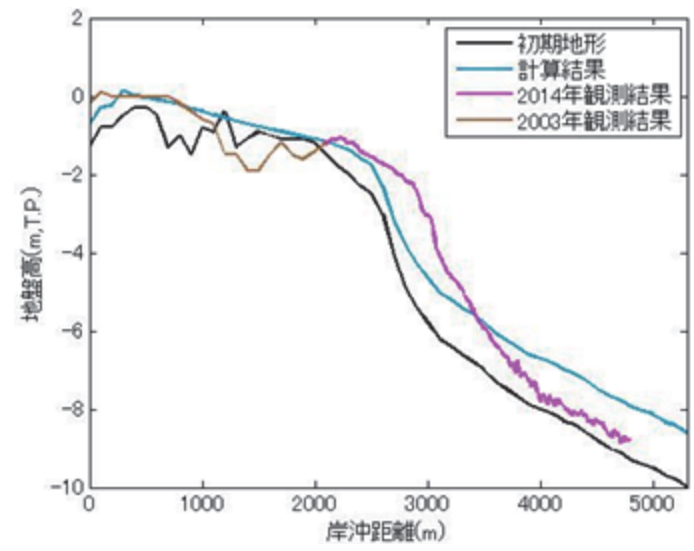

Fig. 11 Comparison of prediction model and measurements of cross-shore profile.

は 2012 年の九州北部豪雨を下回っているものの、 この降雨により多量の土砂が流出し、河口域に被 害を及ぼした。さらに、10月 8 日には阿蘇中岳 の噴火により 51 万 $\mathrm{t}$ 程度の火山灰が放出され、 火口近くには $1.5 \mathrm{~m}$ 程度の火山灰が堆積した。こ のように土砂供給量のポテンシャルの増大と地 盤沈下により河口干潟は長期に及んで影響を受 けることが予想される。

Photo 2 は 6 月 21 日午前 6 時半頃の子飼橋の右 岸から撮影した濁水の流況である。Fig. 12 に豪 雨時の流域の降雨量と河川の水位、河口近くの熊 本新港の潮位変化を示す。子飼橋で水位がピーク に達した時刻と干潮時刻がほぼ一致しており、当 日は大潮でもあったため、水際線が最も沖まで低 下した状態で、白川からの土砂が流入したと考え られる。

Fig. 13 に Fig. 4 と同じ測線の地震後の断面を 示す。地盤沈下の影響により沖側 $1000 \mathrm{~m}$ 以降の 計測が困難となっている。地震後は一様に地盤が

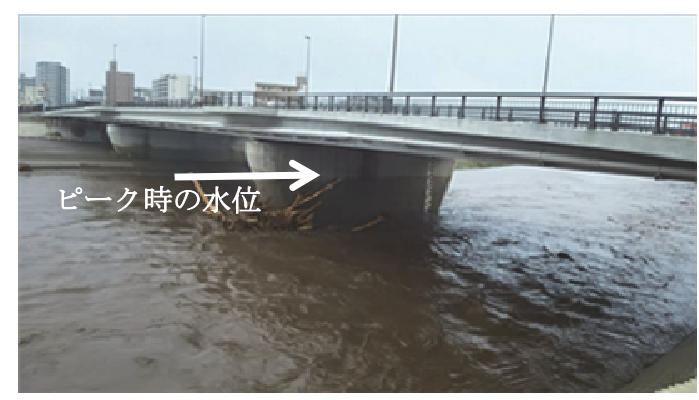

Photo 2 Shirakawa River at Kokai Bridge.
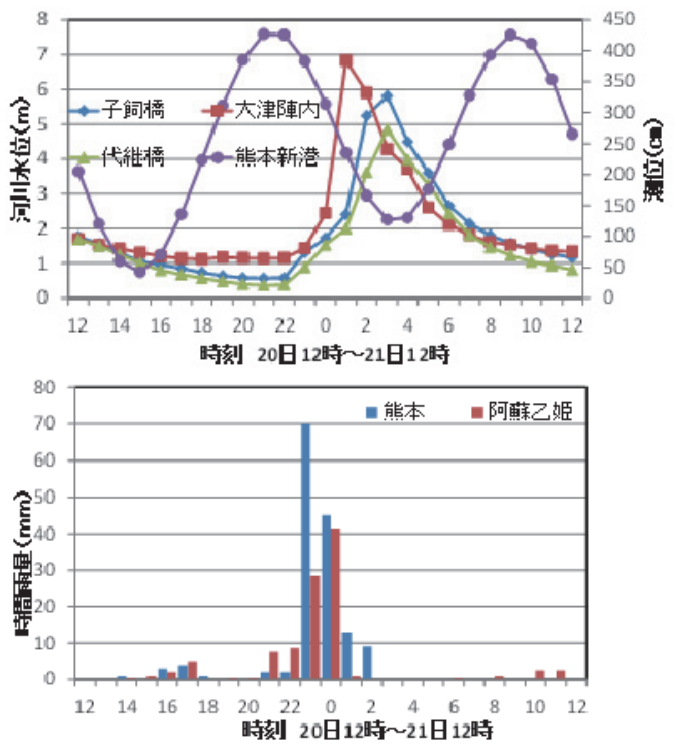

Fig. 12 Time variations of water level, tide level and amounts of precipitation.

低下し、2 年余り経過している範囲において沖側 の低下量が大きくなっている。

Fig. 3 における測線(5)の断面形状を Fig. 14 に 示す。潮下帯での前置層の前進は、1976 年〜2016 年の 40 年間で 600〜 700 $\mathrm{m}$ の前進があり、熊本地 震後の 2014 年〜2016 年の 2 年間で約 $150 \mathrm{~m}$ の前 進が見られた。左岸側の岸沖断面形状を示す。観 測時の潮位にもよるが、地震前は沖側 $1500 \mathrm{~m}$ 付 近まで観測が可能であったが、地震後は地盤沈下 により $1000 \mathrm{~m}$ 付近までに制限されている。

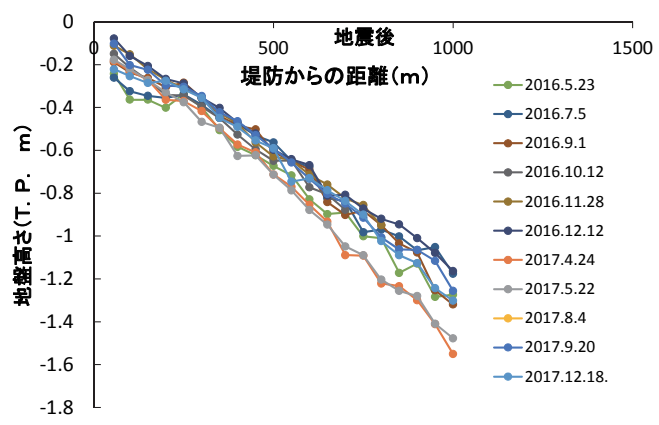

Fig. 13 Measured cross-shore profiles after Kumamoto Earthquakes. 


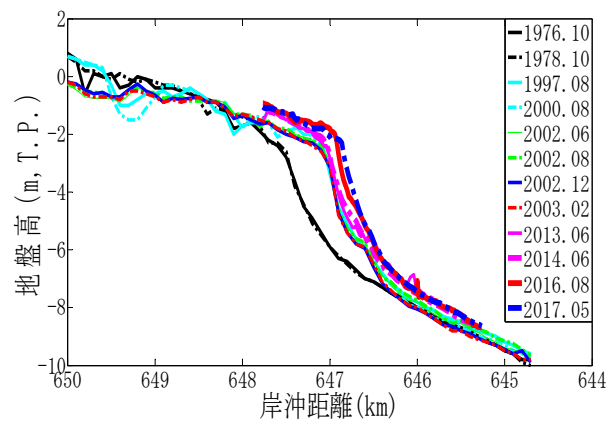

Fig. 14 Measured cross-shore profiles in the subtidal area.

白川河道からの流出土砂量は栗山ら[11]による 算定式があるが、地震後において見直しを行った。 河川流量が多い場合は栗山ら同程度の土砂量と なるが、流量が少ない場合は、流出土砂量が多く なっており、地震後において土砂供給量のポテン シャルが増大していることが伺える。

\section{9 疑似海面上昇下の将来地形変動予測[11]}

熊本地震による地盤沈下を将来に起こりえる 海面上昇とみなし、また、白川からの土砂供給量 も増大し、国と県では定期的に土砂の撤去が行わ れている。そこで 4.7 で説明したプロセスモデル を用いて、新たな地盤高や土砂流入量を用いて、 将来の平衡断面地形の検討を行った。

\subsection{0 河口干潟の平衡断面[10]}

干潟の地形変動を予測するためには、砂浜で適 用される Brunn 則に相当する関係がないため、4.7 で説明したプロセスモデルが用いられている。し かしながら、不確定要素である外力のシナリオの 与え方が極めて重要である。白川河口干潟では 2000 年から地盤高の観測が実施されており、こ れらの観測データを活用して、開水路の平均流速 分布の予測や砂浜の平衡断面予測への適用事例 がある最大情報エントロピーの概念を用いて、河 口干潟の将来の平衡断面形状を検討した。

Fig. 15 に結果を示す。現地では平衡状態が存 在しえないため、エントロピーの概念では観測值 から起こりえる形状を 3 種類の方法に基づき平 衡断面を算定した。その際には地形変化量の累積 確率密度の与え方が重要であり、将来の平衡断面 形状では潮間帯が低下する結果となり、著者らが 行った物理的プロセスモデルによる結果に類似 している。

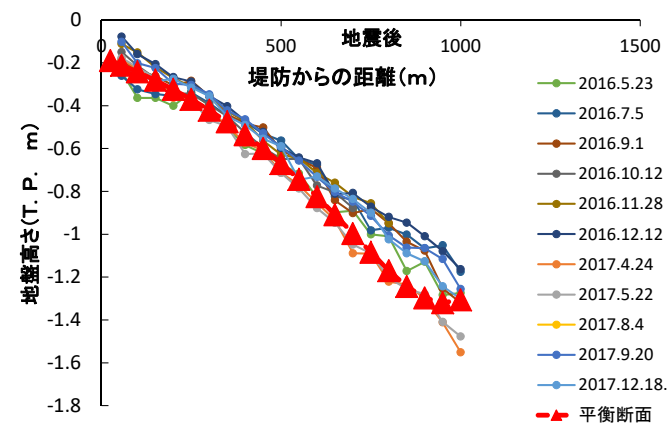

Fig. 15 Equilibrium cross-shore profile.

\section{5. まとめ}

有明海の干潟に関しては、滝川清熊本大学名誉 教授より 1998 年から開始され、その中で白川河 口干潟に着目した研究は、故山田文彦教授の応用 海岸研究室が 2000 年 12 月から本格化に取り組ん だ。当初、主として潮間帯の地形変動や底質移動 に着目し、2012 年の九州北部豪雨後から潮下帯 の地形変化にも視点を拡大し、潮間帯と潮下帯を 含めての地形変動の将来予測を試みていた。著者 が引き継いだ 2016 年に熊本地震、集中豪雨、阿 蘇中岳の噴火等、河口干潟に及ぼす環境が著しく 変化しており、現地観測は継続中である。

\section{謝 辞}

論文における現地観測は、故山田教授が熊本大 学工学部技術部の外村隆臣氏、応用海岸研究室の 卒業生、学生諸氏、大阪市立大学工学部中條壮大 講師と共同で行ったものである。また、観測を行 うにあたり沖新漁業協同組合、小島漁業協同組合 に御配慮頂いた。深浅測量データは国土交通省九 州整備局熊本河川国道事務所、熊本港湾事務所、 熊本県農林水産部水産局漁港漁場整備課より頂 いた。また、白川河口干潟の研究をまとめる機会 を日本混相流学会より提供して頂いた。ここに記 して謝意を表します。

\section{参考文献}

[1] Iseri, E., Okada, T., Akiyama, Y., Watanabe, K. and Kuwae, T., A New Method for the Quantitative Evaluation of Services of Tidal Flats, Technical Note of National Institute for Land and Infrastructure Management, No. 890 (2016).

[2] Nakamichi, M., Yamada, F., Hokamura, T., Tamaki, A. and Kobayashi, N., Mechanism of 
Deposition and Erosion on Mudtidal Flat by Seasonal Tide Level Variation, Journal of Japan Society of Civil Engineering, Coastal Engineering (in Japanese), Vol. 52, 526-530 (2005).

[3] Yamada, F., Sakanishi Y., Yamaguchi, R., Kamohara, S., Anai H., Kobayashi, N., Tamaki, A., and Tada A. Time-Space Distribution of Suspended Sediment Transport Fluxes over Intertidal Mudflat Using Tidal Phase Averaging, Journal of Japan Society of Civil Engineering, Coastal Engineering (in Japanese), Vol. 54, 626-630 (2007).

[4] Yamada, F., Sakanishi, Y., Shirakawa, Y., Anai, H., Hokamura, T. and Kobayashi, N., Conceptual Model for Cross-Shore Sediment Transport due to Tides and Waves over Intertidal Flat, Journal of Japan Society of Civil Engineering, Coastal Engineering (in Japanese), Vol. 55, 461-465 (2008).

[5] Yamada, F., Shirakawa, Y., Anai, H., Kusaai R., Sakanishi Y., Yamamoto, K. and Kobayashi, N., Sediment Budget Based on the Mass of Silt and Clay on Intertidal Flat Adjacent to the River Mouth, Journal of Japan Society of Civil Engineering, Coastal Engineering (in Japanese), Vol. B2-65, No. 1, 476-480 (2009).

[6] Yamada, F., Shirakawa, Y., Funakoshi, Y., Tagawa, K., Hokamura, T., Sakanishi, Y., Kobayashi, N., Tamaki, A. and Tada A., Relative Importance of Tide and River Discharge on Sediment Transport on Intertidal Flat, Journal of Japan Society of Civil Engineering, Coastal Engineering (in Japanese), Vol. 66, (1), 531-535 (2010).

[7] Manu, L., Shiraishi H., Ito, M., Hokamura, T., Nakajyo S., Kobayashi, N., Kuroiwa M., and Yamada F., Relative Importance of Tide and River Discharge on Sediment Transport on Intertidal Flat, Journal of Japan Society of Civil Engineering, Coastal Engineering (in Japanese), Vol. 69, No. 2, I_631-I_635 (2013).

[8] Manu, L., Tsukamoto, T., Nakanishi K., Shirouzu, H., Hokamura, T., Nakajyo S., Kuriyama Y. and Yamada, F., Long-term Evolutions of Shirakawa River Delta due to The Extreme Event, Journal of Japan Society of Civil Engineering, Ocean Engineering, Vol. 70 (2), I_612-I_617 (2014).

[9] Nakanishi K., Nakajyo S. and Hokamura, T., A Basic Study of Estuary Delta Topography
Long-Term Predictive Model Which Can Consider a Future External Force Change, Journal of Japan Society of Civil Engineering, Coastal Engineering (in Japanese), Vol. 71, (2), I 505-I 510 (2015).

[10] Tsujimoto, G., Hokamura, T., Tabata, K., Ohta, H., Nakajyo, S. and Takano, Y., Morphological Changes and Sediment Transport Discharge at the Mouth of Shirakawa River after Kumamoto Earthquake, Journal of Japan Society of Civil Engineering, Coastal Engineering (in Japanese), Vol. 73 (2), I_601-I_606 (2017).

[11] Yamaguchi, $\bar{R}$., Yukimura, R., Hokamura, T. and Tsujimoto, G., Morphological Changes and Long-Term Equilibrium Delta Profile at the Mouth of Shirakawa River Based on Information Entropy Concept, Journal of Japan Society of Civil Engineering, Coastal Engineering (in Japanese), Vol. 74 (2), I_811-I_816 (2018).

[12] Yamaguchi, R., Tsujimoto, G. and Hokamura, T., A Study of Long-Term Prediction on Estuary Delta Topological Changes under Pseude Sea Level Rise after Kumamoto Earthquake, Journal of Japan Society of Civil Engineering, Ocean Engineering (in Japanese), Vol. 74, (2), I_725-I_730 (2018).

[13] Yamaguchi, R., Tabata, K., Tsujimoto, G. and Tsujimoto, G., Amount of Sediment Discharge from Shirakawa River and Morphological Changes of Tidal Flatt after Kumamoto Earthquake, Journal of Japan Society of Civil Engineering, Coastal Engineering (in Japanese) Vol. 74 (2), I_713-I_718 (2018).

[14] Swenson, J. B., Paolo, C., Pratson, L., Voller, V.R. and Murray, A. B., Fluvial and Marine Controls on Combined Subaerial and Subaqueous Delta Progradation: Morphdynamic Modeling of Compound-Clinoform Development, Journal of Geophysical Research, Vol. 110, 1-16 (2005).

[15] Mariotti, G. and Fagherazzi, S., A Numerical Model for the Coupled Long-Term Evolution of Salt Marshes and Tidal Flats, Journal of Geophysical Research, Vol. 115, F01004 (2010).

[16] Kuriyama, Y. and Hashimoto, K., Sediment Budget on an Intertidal Flat at Mouth of the Shirakawa River, Japan, Technical note of the Port and Harbor Research Institute (in Japanese) Vol. 1704, 1-16 (2004). 